\title{
HMDを利用した航海情報の表示に関して \\ Presentation of Navigational Information by Using Head Mounted Display
}

古谷 雅理 ${ }^{1} \cdot$ 羽子田 哲弥 $^{2} \cdot{\text { 大石 } \text { 浩世 }{ }^{3} \cdot \text { 軸丸 祐策 }}^{4}$

\author{
Tadasuke FURUYA, Tetsuya HANETA \\ Hiroyo OISHI and Yusaku JIKUMARU
}

\begin{abstract}
According to the reports over the last 5 years, a human error accounts for about 80 percent of causes in marine traffic accidents. Navigational instruments like ECDIS are useful for relieving crew members from their work load and supporting navigation, however our overconfidence in their instruments make us cause marine accidents. Therefore, watching is especially important.

In this study, we provide a new way to indicate navigational information by use of HMD. We project a panoramic video generated from cameras attached at ship's mast to HMD and overlay the navigational information of other ships. Proposed display method becomes an efficient information support because view of a person who wears HMD follows person's head motion. We display 6 kinds of information which are own ship state, other ship states, radar, chart, panoramic video and a bird's-eye view of own ship.
\end{abstract}

Keywords : Information Processing, Information Support, Navigation Support, Head Mounted Display キーワード : 情報処理, 情報支援, 航海支援, Head Mounted Display

\section{1.はじめに}

過去 5 年間の統計において日本近海での海難事故 は減少傾向にあるが、衝突事故が占める割合は、28\% と最も高いことが海上保安庁のレポート ${ }^{(1)}$ で報告さ れている。さらに、衝突事故原因の 8 割以上を占め るのは、見張り不十分・操船不適切といった人的要 因である。見張り支援としてさまざまな航海計器が 作成され、操船時における安全航行の判断材料とし ての役割を担っている。しかし、航海計器の表示を 過信したことによる座礁事故の例もあり、目視での 見張りは非常に重要である ${ }^{(2)}$ 。そこで本研究では、 航海計器から得られる情報と目視による見張りから 得られる情報の両方を重要視した見張り支援手法を 提案する。
目視で得られる情報を重視した見張り支援の手法 として、船舶に取り付けた魚眼カメラから船舶周辺 映像を取得し、見張りに役立てる研究が報告されて いる ${ }^{(3)}$ 。また、航海計器から得られる情報を重視し た見張り支援の手法として、取得した映像にレーダ 画像や自動船舶識別装置（AIS：Automatic

Identification System)、自船航海情報を統合表示 するシステムが提案されている(4) (5) (6)。さらに、利 用者の視界と重祆て情報表示可能な HUD (Head-Up Display)や、ウェアラブル端末である HMD (Head Mounted Display)の利用が見張り支援に検討されて いる ${ }^{(7)}{ }^{(8)}$ 。本研究では、操作性、携帯性に優れると いった利点から、航海情報表示のための表示装置と してHMD を利用する。HMD 上に自船舶を中心とした 3

\footnotetext{
正会員 東京海洋大学 （干135-8533 東京都江東区越中島 2-1-6）

学生会員 東京海洋大学（干135-8533 東京都江東区越中島 2-1-6)

学生会員 東京海洋大学（干135-8533 東京都江東区越中島 2-1-6)

非会員 東京海洋大学（干135-8533 東京都江東区越中島 2-1-6）
} 
次元仮想空間を作り、自船の航海情報、船舶周辺の 映像に加えて他船 AIS 情報を表示することで周囲の 環境を簡易に再現する。他船 AIS 情報の表示は実験 に利用する東京海洋大学練習船「汐路丸」の航行海 域、速度から $5 \mathrm{NM}$ 以内の船舶を対象とした。また、 提案手法の表示が適切であるかどうかについて、実 際に航行中の船舶船橋にて検証した。

\section{HMDを利用した航海情報表示概要}

船舶上部マス卜に設置した IP カメラから得られ る船舶周辺映像、魚眼 IP カメラから得られる船舶俯 瞰映像などの映像情報、AIS 情報、航海データ、電 子海図、レーダの 5 種類の情報を加工し、HMD 上に 統合表示寸る。図 1 に本研究で使用した 0culus 社の HMD である 0culus Rift DK2 (画面解像度: $1920 \times 1080$ 、 視野角：水平画角 115 度、垂直画角 105 度、リフレ ッシュレート：75Hz）を示す。

図 2 に、取得する 5 種類の情報を HMD に出力する までの概要を示す。いずれのデータも船内 LAN 経由 で取得する。AIS 情報は船内 AIS 受信機から、航海 データは船内に設置してある計測サーバから取得す る。映像は 2 種類あり、船舶船橋上マストに設置さ れた 6 台の IP カメラから得る船舶周辺映像と、1 台 の魚眼 IP カメラから得る船舶俯瞰映像を扱う。海図 映像は電子海図表示 PC の映像信号を、レーダ映像は 船内レーダ機器から映像信号を取得する。これらの 情報をHMD 表示用 PC 内で加工し、HMD へ表示する。

船舶周辺映像は、6 台の IP カメラから取得した映 像を補正、結合、切り出しの順で処理を加えた 360 度のパノラマ映像である。この映像を、HMD 装着者 （3 次元仮想環境内での視点）を中心とした仮想空 間内の円柱側面にテクスチャとして貼り付けること で、HMD 装着者は船舶船首から船尾までの周辺の様 子を頭の回転の動きに合わせて確認することが可能 となる。この円柱の上面は空、底面は自船舶に相当 寸る。この部分に自船情報、船舶俯瞰映像を表示す る。

航海データには船速、船位、船首方位、舵角、風 向風速などが含まれており、毎秒更新される。この 自船情報加 、自船速度、船首方位、風向風速情報 を船舶周辺映像の上部（仮想環境内の円柱上面）に 表示する。

他船情報は船舶周辺情報に重祇て表示寸る。自船 航海デー夕に含まれる自船緯度経度と、受信した AIS 情報に含まれる他船緯度経度から、船舶周辺映

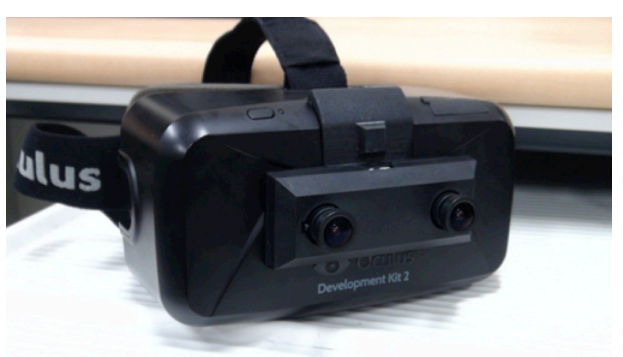

図 1 本実験で使用した Head Mount Display

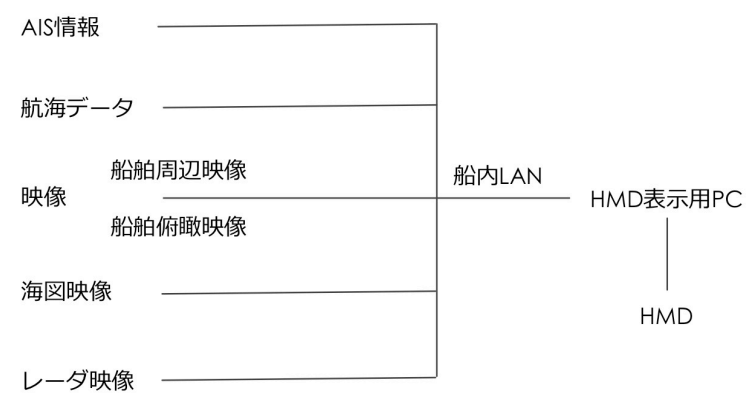

図 2 データ入出力流れ

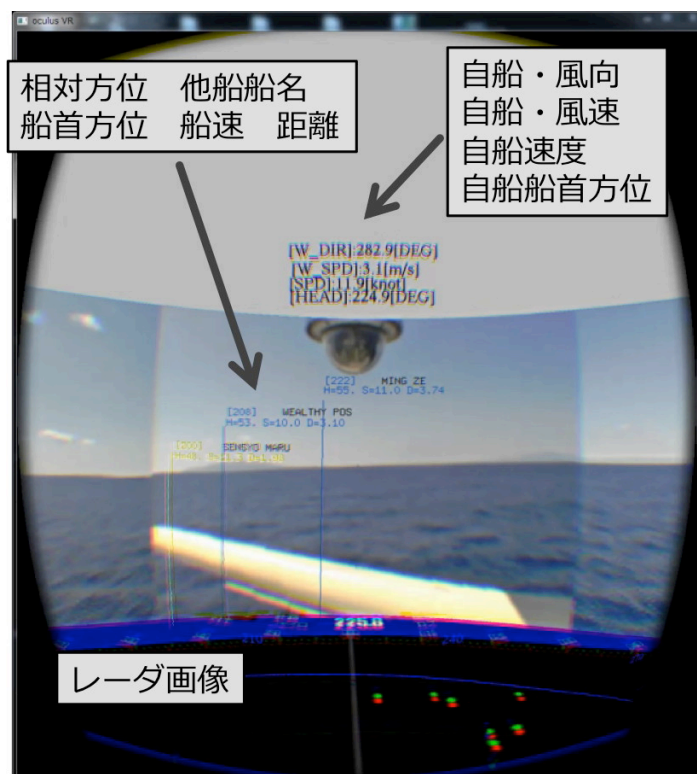

図 3 HMD 表示画面

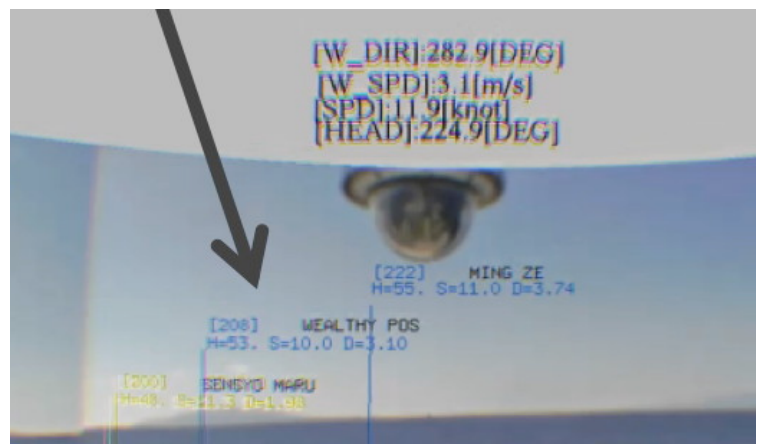

図 4 HMD 表示画面（拡大表示） 
像上における他船舶位置を求める。この他船舶位置 に、AIS 情報に含まれる他船のMMSI (Maritime Mobile Service Identity）番号、船名、船速、船首方位、 目的地などの船舶動静データに加え、二船の相対方 位、他船までの距離を表示する。

視界不良時の対応として、船舶周辺映像の下部(仮 想環境内の円柱底面）にレーダ映像を表示する。30 度以上鉛直下向き頭部を移動させた場合、レーダ映 像から船舶俯瞰映像に切り替えて表示する。頭部の 向きを水平付近まで戻すとレーダ映像表示に戻る。

図 3 に自他船情報の表示例を示す。自他船情報を 拡大した様子を図 4 に示す。船首方向左舷方向に 3 隻の船舶がおり、自船が 11.9 knots で航行している ことがわかる。船舶俯瞰映像を表示寸ることで、航 行中のみならず、例えば着岸時において、自船と岸 壁の関係を俯瞰的に見ながら状況を把握することが 可能と考える。

視線方向と正対する位置に海図を表示することで 自船位置を確認する。キーボードのあるキーを押下 寸ることで表示の有無を切り替える。この操作はキ 一ボード位置がわかる状態で行う。

本研究では、視界内の船舶との衝突までの指標表 示を試みた。物標の速度、針路から自船との最接近 点 (CPA: Closest Point of Approach)を求めること で、最接近時間 (TCPA：Time of CPA) ${ }^{(9)}$ および最接 近距離(DCPA：Distance of CPA) (9) 求め、表示す る。図 5 に他船の TCPA、DCPA を他船の MMSI 番号、 船速などとともに表示した例を示す。特別な操作な く5NM 以内の船舶の情報が表示される。

このように、目視の代わりとしての IP カメラ、魚 眼 IP カメラと各種航海計器から得られる情報を 1 台の HMD に統合表示寸ることで、簡易に船舶周辺の 環境を再現し、見張りを補助する。ただし、表示す る情報量は、情報確認や判断時間に影響を与える。 表示情報に関しては今後再検討する。

\section{3.仮想空間の構築}

周辺映像、自船航海データ、他船 AIS 情報を表示 する仮想環境を構築する。周辺映像と自他船の位置 関係について図 6 に示す。仮想空間に自船周辺の環 境を再現し、3 次元仮想環境内での視点から見える 領域をHMD に表示寸る。3 次元仮想環境を使用した 情報の表示には先行研究の手法 ${ }^{(5)}$ を利用する。

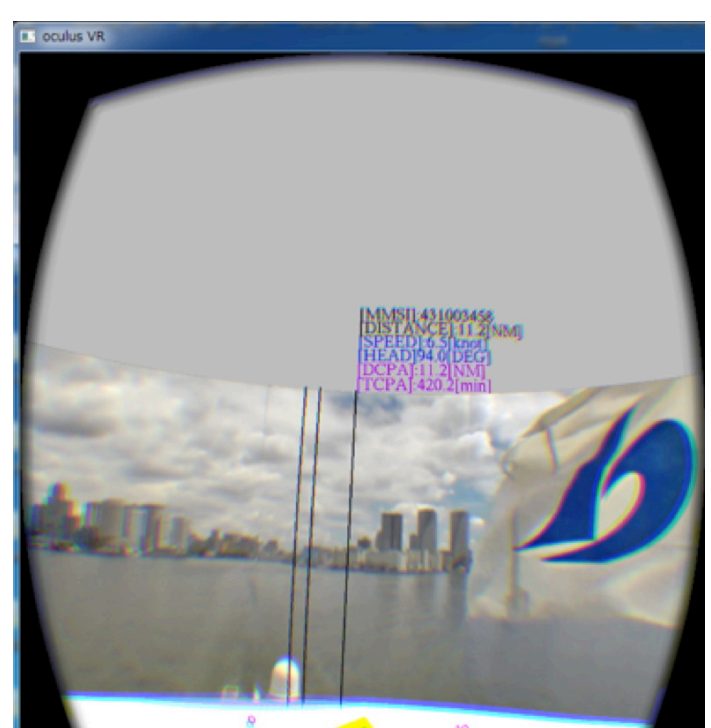

図 5 他船情報（TCPA、DCPA、MMSI 番号、船速）

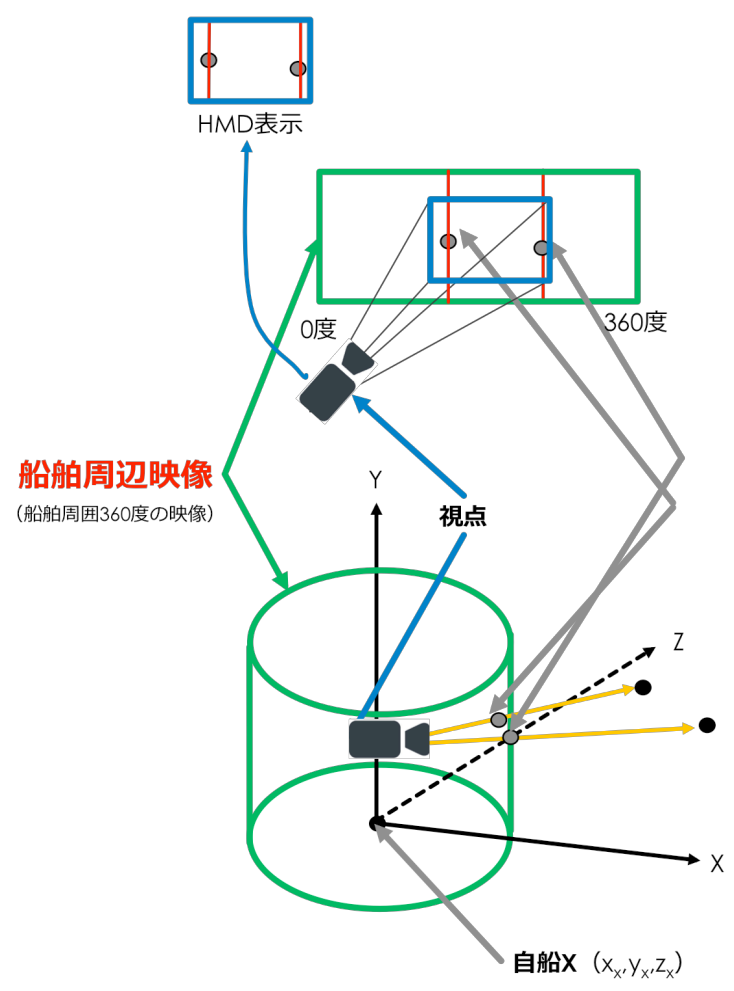

図 63 次元仮想環境における船舶周辺映像と 他船の位置

\section{1 映像合成}

自船マスト上部に同一円周上に設置した 6 台の IP カメラで全方位の映像を撮影する。これらの映像を 横方向につなげることで、1 つの映像として出力す る。この映像が船舶周辺映像である。使用した IP カメラのフレームレートは $30 \mathrm{fps}$ 、水平画角は 124.5 度、最高解像度は $1920 \times 1080$ であるが、処理の高速 化のため解像度を $470 \times 270$ とした。

船舶周辺映像の作成の流れを図 7 に示寸。IP カメ 


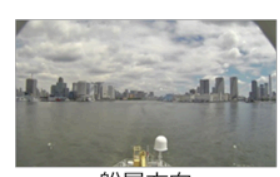

船尾方向

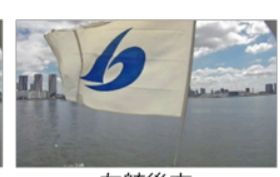

左舷後方

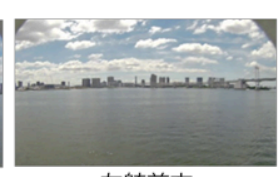

左舷前方

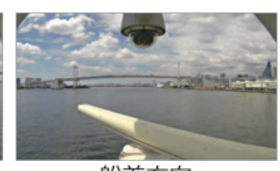

船首方向

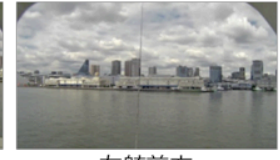

右舷前方

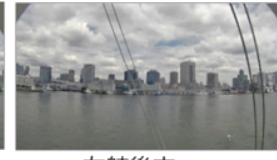

右舷後方

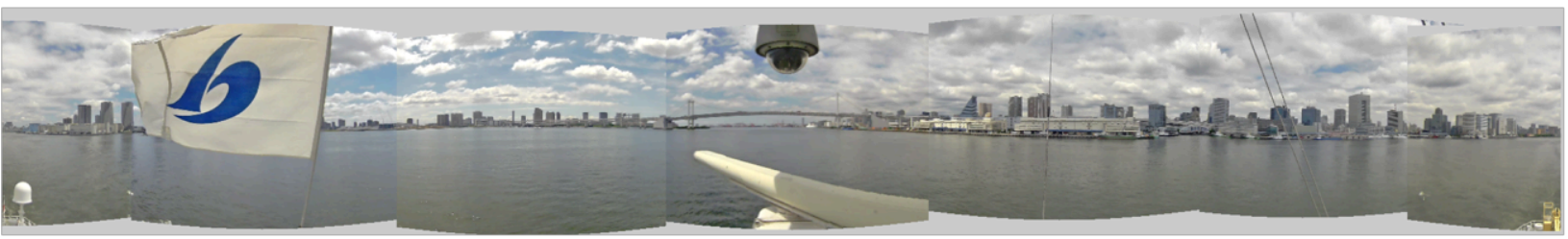

映像の歪曲化（円柱投影のため），結合

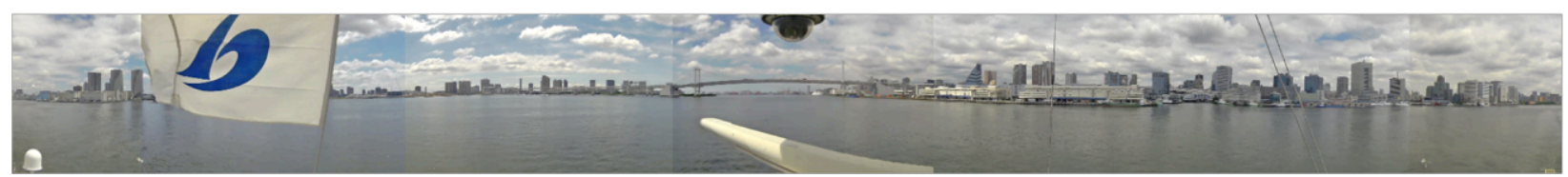

結合映像切り出し，出力

図 7 映像加工流れ

ラで撮影した映像（図 7 上段）には、中央から外側 に向かって、膨らんだように見える歪曲収差が発生 するため、この歪みを補正する。また、補正処理後 の映像の投影先は円柱面であるため、平面の映像を 円柱面の曲面の形に合わせるように補正する。その 後、6 台の IP カメラの撮影範囲が重ならないように トリミングし各映像を結合する (図 7 中段)。図 7 下段は不要な領域を除去して作成した船舶周辺映像 である。IPカメラの設置位置は固定されているため、 結合位置決めはIP カメラ設置時の一度でよい。結合 後の船舶周辺映像の解像度は $2032 \times 210$ であり、こ れを図 6 に示す仮想空間上に設置した円柱(半径 154 、 高さ100）の側面に貼り付ける。円柱の中心は自船 に設置した 6 台の IP カメラの中心位置である。3 次 元仮想環境内での視線方向を HMD 装着者の頭部の回 転に追従させることで、船橋内においても後ろを振 り返る動作だけで船尾の様子を把握することが可能 である。HMD 付属の近赤外線 CMOS センサから HMD 装着者の顔の向きを取得することで表示に利用する 映像を限定し、更新処理することで、映像取得から 描画までの時間を短縮する。

\section{2 他船情報の投影}

3.1 節で作成した船舶周辺映像は自船（HMD 装着 者）を中心とする円柱にテクスチャとして張り付け られている。始めに、船内サーバから配信される自 船の緯度経度と船内 AIS 情報送受信機で受けている 他船の緯度経度から船舶周辺映像上での他船位置を 決定する。次に、自船から見た他船の方位に該当す
る位置に円柱の高さ方向（図 6 の Y 軸）と平行な直 線を引き他船位置を示す。他船の位置を点ではなく、 線で表示することで、利用者は短時間で他船の存在 する方向を認識可能である。また、他船との距離を 色覚的に識別するため、直線の色を自船と他船の距 離に応じて変える。自船から $1 \mathrm{NM}$ 以内の船舶は赤色、 $1 \mathrm{NM}$ から 2NM 以内に位置する船舶は黄色、2NM 以上離 れている船舶は青色の線を用いて表示し、航行して いない船舶（速力 1 knot 以下）は黒色で表示する。 線が引かれた位置と線自体の色から、現在、AIS 搭 載船舶がどの方位に何隻存在し、何 NM 離れているか 視認できるため、自船周囲の状況把握が容易である。 さらに詳細な情報を得る場合は、船舶周辺映像上の 他船付近に描画される AIS 情報を読み取る。この他 船 AIS 情報は、船舶周辺映像の半分よりも上の領域 に自船から距離の近い順に、最大 5 隻表示する。水 平方向の表示が重なり見難いときがあるので表示方 法に関して今後さらに検討する。

船舶周辺映像上の他船位置は中分緯度航法により 求めた。中分緯度航法を使用する場合、高緯度、長 距離においての計算で誤差が生じるが、本研究では $5 \mathrm{NM}$ 以内の船舶を対象としているため、誤差は無視 できると考える。計算式は以下の通りである。

$$
\begin{aligned}
& \text { midlat }=\frac{(\text { lat } 0+\text { lat } 1)}{2} \\
& \text { Dep }=(\operatorname{lon} 1-\operatorname{lon} 0) \times 60 \times \cos (\text { midlat }) \\
& \text { D. } l=(\text { lat } 1-\text { lat } 0) \times 60 \\
& \text { Dist }=\sqrt{D \cdot l^{2}+D e p^{2}} \\
& \psi=\tan ^{-1}\left(\frac{D e p}{D . l}\right)
\end{aligned}
$$


ここで lat0 とlon 0 は自船の緯度経度を示す。lat1 とlon 1 は他船の緯度経度を示す。midlat $は$ 中分緯度、 Dep は経度差、D. 1 は緯度差であり、Dist は自他船 の距離を示す $\phi$ は北を 0 度とした場合の自他船の相 対方位である。求めた $\varphi$ 、自船の船首方位から船舶 周辺映像上での他船舶の座標計算をおこなった。自を 船の緯度経度は船内サーバから毎秒取得され、他船 の緯度経度は船内情報送受信機から他船の航行状況 に応じて取得されるが、AIS 情報内の動的情報は他 船の航行状況によって送信間隔が異なる。例えば、 Oknots から $14 \mathrm{knots}$ まで航行する船舶の AIS 情報送 信間隔は 10 秒である。また、14knots から 23knots で航行する船舶の場合は 6 秒である。日本近海にお いて、14knots から 23knots で航行する船舶は少な くない。変針中においてはこの限りではないが、最 後に取得したAIS 情報を使用して描画をおこなうと、 他船の描画位置に 6 秒分の誤差が発生してしまう。 この問題については、自他船の進路と船速から線形 外挿により 1 秒先の緯度経度を予測することで対応 する。

\section{4.実験}

2017 年 1 月から 3 月にかけて提案手法の基本性能 の検証と、検証結果を踏まえた機能の追加および再 検証を実施した。

\section{1 実験概要}

提案手法の動作確認および性能を検証するため、 実験は 1 月 17 日から 19 日、2月 21 日から 23 日、3 月 7 日から 9 日の 3 回実施した。いずれの実験も東 京海洋大学練習船「汐路丸」の航行中に実施し、実 験海域は東京湾晴海一館山間である。実験は練習船 船橋にHMD を接続した PC を設置し、HMD に表示され る映像と、実際に船橋から目視できる周囲の景観、 および、船橋内前方に設置された ECDIS (Electronic Chart Display and Information System) 画面と比 較することでおこなった。

実験は昼夜間おこない (図 8 上段、中段)、船舶周 辺映像、船舶俯瞰映像、レーダ映像、電子海図の表 示および切り替えがそれぞれ正常におこなわれるか、 AIS 情報の配置、配色共に正しく表示されるか、HMD の表示内容とレーダ、ECDIS、目視との差について検 証した。HMD に繋いだ PC のディスプレイをECDIS 画 面の隣に設置することで、HMD に表示されている映 像とECDIS の画面を比較した(図8下段)。実験には、
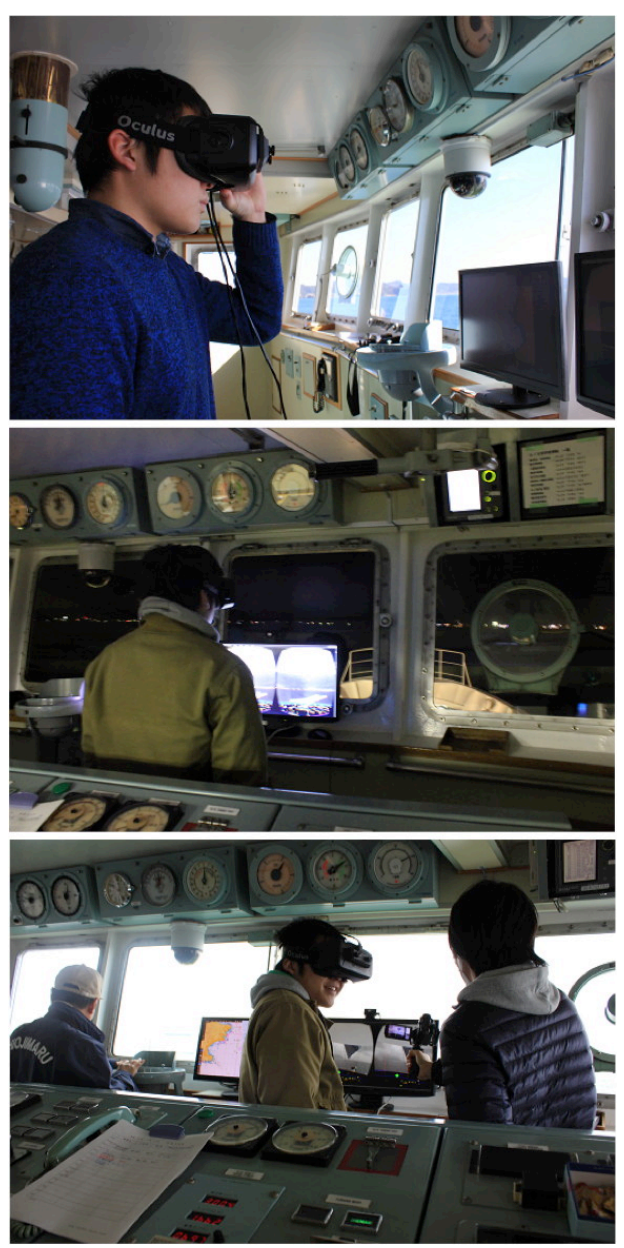

図 8 実験の様子

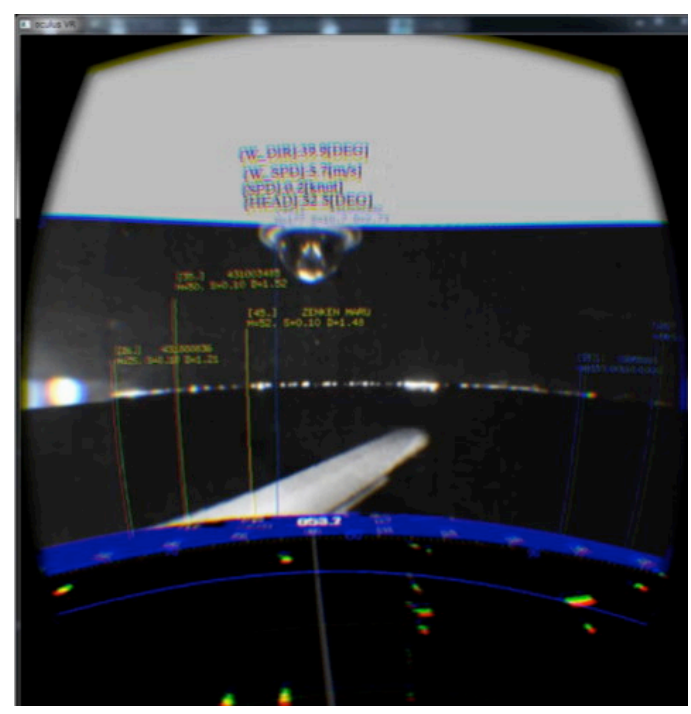

図 9 夜間の HMD 表示画面

マスト周囲(高さ $13 \mathrm{~m}$ ) に設置した 6 台の IP カメラ、 マスト先端付近（高さ18m）に設置した魚眼 カメラを使用した。

図 9 に夜間の HMD 表示画面を示す。自船と他船の 距離に応じて変える直線の配色は夜間も日中と同じ 

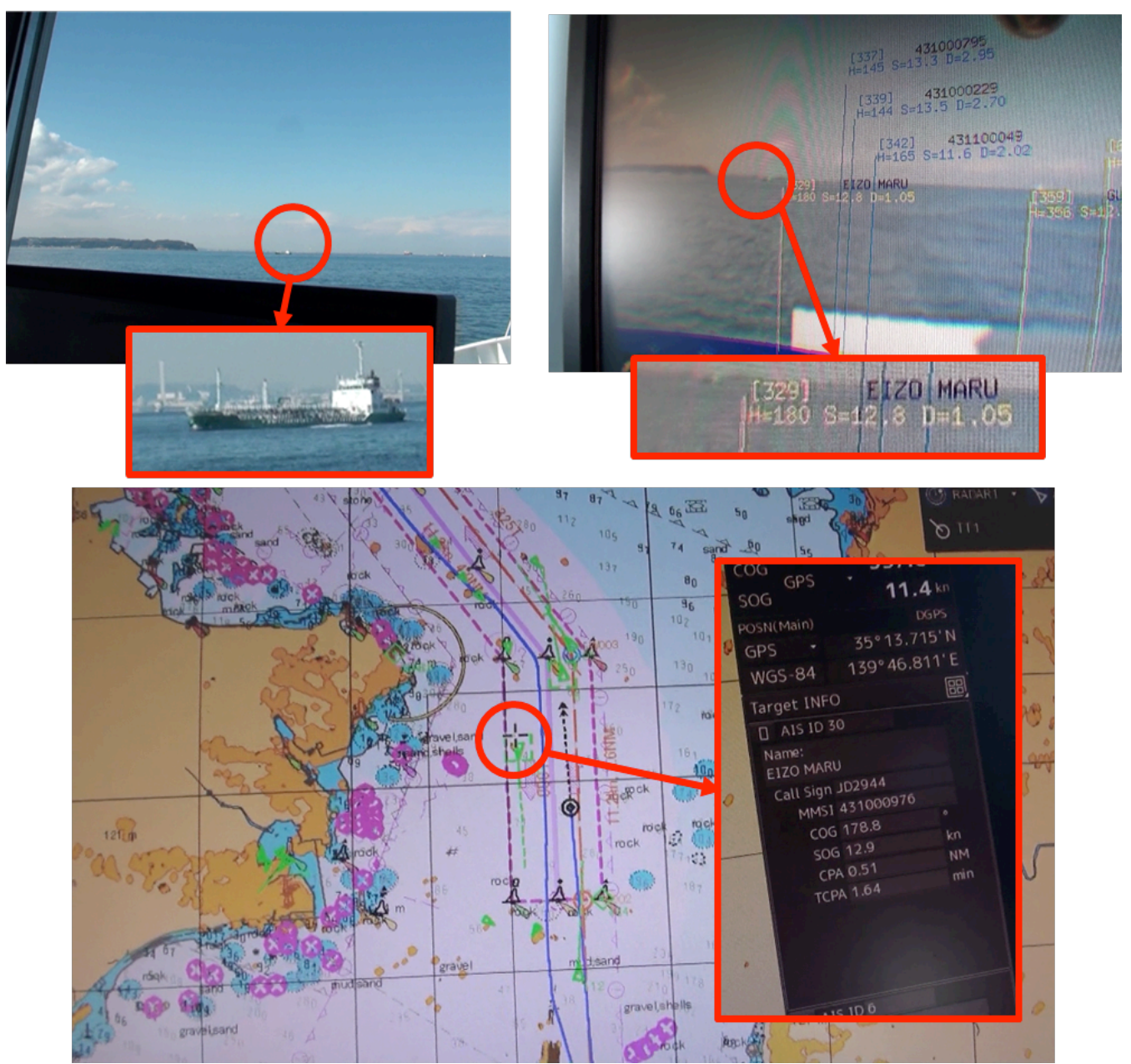

図 $10 \mathrm{HMD}$ 表示の検証結果（左上：デジタルカメラ画像、右上：HMD 画面、下： ECDIS 画面）
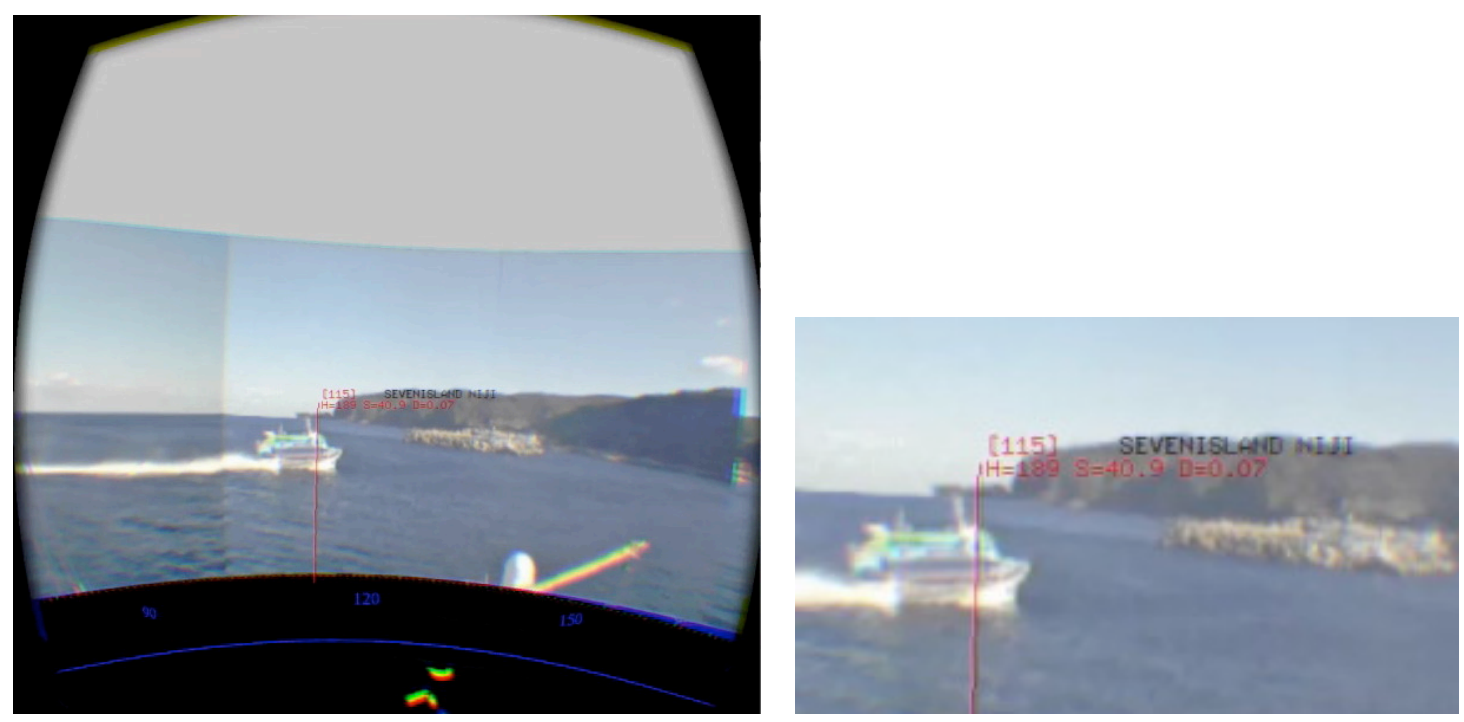

図 11 高速ジェット船の HMD 表示

であるが、速力 1 knot 以下を示す黒線以外は彩度を 落とした。実験海域は完全な暗闇でないため黒い線 も十分識別可能であった。

\section{2 表示検証}

検証用に実験時の様子をデジタルカメラで記録 した。図 10 は練習船の同航船を船橋内からデジタル 
カメラ、HMD、ECDIS の 3 つの手段において、同時刻 に確認した結果画像である。デジタルカメラで撮影 された船舶（図 10 左上）が、HMD の画面（図 10 右 上）に表示されていることが、ECDIS 画面（図10下） から分かる。

図 11 左は伊豆大島に向かう高速ジェット船を HMD からキャプチャした画像である。高速船を拡大表示 したものを図 11 右に示す。高速で航行している高速 ジェット船を船舶周辺映像上で追尾し、自船との距 離に応じた色で船舶位置に縦線が引かれ、AIS 情報 情報の一部が表示されている。これらの值は AIS 情 報が更新されるたびに更新される。船内 AIS 情報受 信機から受けた他船 AIS 情報を基に位置を推測し、 船舶周辺映像内に他船情報が描画されること、目的 地と船名が 1 秒おきに切り替わることを確認した。

\section{3 評価}

乗組員を含む乗船経験者が、本システムを試行、 評価した。下記に示すように HMD に情報を表示する ことに関しては良好な評価である。

・ 航海、レーダ、海図などの情報と船舶周辺映像 が同一視界内に表示されるため、情報把握が容 易である。

・船舶周辺映像で全周囲を見渡すことができるた め、その場で頭を回転させるだけで船尾方向も 船橋内で確認できる。

・相手船が AIS を搭載している場合において、視 界不良時においても他船の位置・情報が把握可 能である。

・ 複雑な操作が無く、任意の情報が任意の場所で 確認できる。

・ AIS 情報に目的地が含まれていた場合、船名と 1 秒おきに表示を切り替えたが、他船船首方位、 他船船速、他船までの距離などの情報は表示さ れているので特に問題ない。

表示内容に関して今後改善すべき評価を記す。

・ 船舶の航行状態によって AIS 情報の送信間隔が 変化するため、他船の表示位置がずれてしまう 場合がある。

・ 停泊船が多い場所では HMD の表示圈内に船舶が 多数存在し、HMD 上に情報が密集して表示され るため、表示が分かりにくい場合がある。
船舶が発信する AIS 情報には Class A、Class B の 2 種類がある。SOLAS (International Convention for the Safety of Life at Sea）により搭載義務の 定められている船舶が積載する AIS 情報は Class A である。船舶が航行している場合、Class A の動的 情報の送信間隔は最長でも 10 秒であるため、3.2 節 で述べた線形的な補間でAIS 情報が更新されるまで の時間を補うことができる。しかし、SOLAS によっ て搭載義務の定められていない船舶が積載する Class B に関して、船舶が対地船速 2 knots から $14 \mathrm{knots}$ で航行する際、動的情報の送信間隔は 30 秒 である。この間に船舶の針路や船速が急に変化した 場合には誤差が発生する。このような船舶に関して は、船舶周辺映像のみから情報を読み取る必要があ る。

\section{5.まとめ}

本研究では、見張り支援の観点から航海計器と目 視による見張りを組み合わせて表示が可能な航海情 報表示システムを提案した。提案システムでは、携 帯性、操作性に優れるなどの点から情報表示装置と してHMD を利用した。また、提案システムの実用性、 表示情報の正確さを検証するために、航行中の船舶 船橋において、HMD に各種情報を表示し、目視、ECDIS 画面との比較をおこなった。

提案手法の特徵は、複雑な操作なしで多種類の情 報取得が可能であり、船舶周囲の状況把握を容易に おこなうことができることである。例えば、船舶周 辺映像に他船舶 AIS 情報を重畳することで、他船舶 の情報を得るために ECDIS 画面を確認するといった 移動の必要がない。さらに、全周映像が表示される ため、背後を振り返るだけで船尾の状況が確認でき る。従来の船橋内外を動き回り情報を拾い集める方 法と比べ、より効率的な情報取得が期待できる。

今後の課題として、利用場所の拡張が挙げられる。 本研究では実験を船舶船橋内でおこなったが、通信 手段を確保することで船橋以外の場所や、陸での利 用も可能である。また、HMD の解像度がこれ以上望 めないこと、PC との接続ケーブルが延長できないこ となど、ハード的な問題が残っている。密閉型 HMD を装着しながらの作業には多くの制約がある。既存 の機器を操作することが困難な場合が多いため手先 が見えなくても利用可能なインタフェースが必要と なる。密閉型 HMD にカメラを接続し、映像を表示寸 るビデオスルー型 HMD も存在するが、解像度、距離 
感などの問題があるためカメラなしと同様に簡易な インタフェースが必要であると考える。

さらに、HMD を長時間装着した場合、平衡感覚に 影響が生じ、乗り物酔いのような症状が発生するこ とが知られている。この症状には個人差があり、船 橋で実験した際には 30 分程度で吐き気等の症状が 出た者や、2 時間以上着用しても特に変化を感じな い者がいた。見張りは基本的に 4 時間交代でおこな うため、HMD の使用方法に関してさらなる検討、検 証が必要である。

\section{参考文献}

（1）海上保安庁：海難の現況と対策について (平成 27 年度版),

http://www. kaiho.mlit. go. jp/info/kouhou/h 28/k20160316/k160316-2. pdf, 2017.3.

（2）竹本考弘：「目視することの重要性」, 海と安 全, No. 563, pp. 6-9, 2014.12.

（3）大山雄佑, 江崎修央, 瀬田広明, 濱地義法 : 魚 眼レンズを用いた自船周りの映像表示技術, 日 本航海学会論文集, Vol. 122, pp. 45-52, 2010.

（4）正田賢次郎, 福戸淳司, 岡崎忠扸：新しい安 全航行支援システム INT-NAV の開発と評価： 景観画像と航行情報を統合表示する先進安全 航行支援システム, 電子情報通信学会技術研究 報告, SSS 安全性, Vol.106, No. 311 , pp. 21-24, 2006. 10.

(5) 長島雄大, 古谷雅理, 稲石正明, 榧野純: 船舶 周囲の監視に関する研究, 日本航海学会論文集, Vol.127, pp. 141-148, 2012. 5.

（6）大石浩世，古谷雅理，羽子田哲弥，櫻田武嗣 : モバイルデータ通信を利用した遠隔地におけ る航行情報表示システム, 日本航海学会論文集, Vol. 135, pp.159-165, 2016. 12.

（7）正田賢次郎, 福戸淳司, 沼野正義, 稲岡孝, 中 藤雅範: 目視認識支援装置の開発, 日本航海学 会論文集, Vol.122, pp. 7-13，2010.

（8）北澤文香, 軸丸祐策, 古谷雅理, 庄司るり： ッドマウントディスプレイを用いた航海支援 に関する基礎研究, 日本航海学会論文集, Vol. 135, pp. 184-193, 2016. 12.

（9）今津隼馬, 榧野純: 新版 電波航法, 成山堂書 店, 2012 . 